\title{
QUALITATIVE AND QUANTITATIVE SCREENING OF SOME PHYTOCHEMICAL COMPOUNDS IN WATERMELON (CITRULLUS LANATUS) SEEDS CULTIVATED IN ESAN WEST LOCAL GOVERNMENT AREA OF EDO STATE
}

\author{
G.E. Irabor \\ Department of Chemistry, Faculty of Physical Sciences, Ambrose Alli University, \\ P.M.B 14, Ekpoma, Edo State, Nigeria. \\ J.E. Ebhoaye \\ Department of Chemistry, Faculty of Physical Sciences, Ambrose Alli University, \\ P.M.B 14, Ekpoma, Edo State, Nigeria. \\ A. Odia \\ Department of Chemistry, Faculty of Physical Sciences, Ambrose Alli University, \\ P.M.B 14, Ekpoma, Edo State, Nigeria.
}

\begin{abstract}
Watermelon (Citrullus lanatus) seeds are often discarded when consuming the fruit. Qualitative phytochemicals screening of the seeds using various solvents and standard methods of analysis revealed the presence of alkaloid, flavonoids, phenol, steroid, carbohydrate, tannins, saponins, phytosterols, terpenoids, and glycosides in various degree of concentration which was also a function of the extracting solvent. In the quantitative assay, alkaloid had the highest percentage composition of $0.57 \%(28.33 \mathrm{mg} / \mathrm{g})$ and flavonoids having the lowest percentage of $0.01 \%$ $(0.67 \mathrm{mg} / \mathrm{g})$. Others include; phenol $0.02 \%(0.76 \mathrm{mg} / \mathrm{g})$, tannins $0.02 \%(1.08 \mathrm{mg} / \mathrm{g})$ and saponins $0.08 \%$ $(16.87 \mathrm{mg} / \mathrm{g})$. This study suggests that the seeds are of high natural medicinal use as well as nutritional values with the identification and quantification of some bioactive chemical constituents.
\end{abstract}

Keywords: Phytochemical, watermelon, seeds, medicinal and bioactive.

\section{INTRODUCTION}

Medicinal plants have bioactive compounds which are used for curing of various human diseases and play an important role in healing. These bioactive compounds, also referred to as phytochemicals can be found in the leaves, roots, flowers and seeds of medicinal plants (Wadood et al., 2013). Medicinal plants constitute the main source of new pharmaceuticals and healthcare products (Ivanova et al., 2005). The history of plants being used for medicinal purpose is probably as old as the history of mankind. The use of medicinal plants in the industrialized societies has been traced to the extraction and development of several drugs from these plants as well as from traditionally used folk medicine. Extraction and characterization of several active phytocompounds from plants have given birth to some high activity profile drugs (Vaghasiya et al., 2011).

A growing body of evidence indicates that secondary plant metabolites play critical roles in human health and may be nutritionally important. It is believed that crude extract from medicinal plants are more biologically active than isolated compounds due to their synergistic effects (Jana, S. and Shekhawat, 2010). Phytochemical screening of plants has revealed the presence of numerous chemicals including alkaloids, tannins, flavonoids, steroids, glycosides and saponins etc. Secondary metabolites of plants serve as defense mechanisms against predation by many microorganisms, insects and herbivores (Vaghasiya et al., 
2011). In Nigeria, the use of traditional medicine is widespread and herbal medicines are popular in the treatment of many diseases due to the belief that they are safe, easily available and with less side effects.

Watermelon (Citrullus lanatus) is a fruit crop and herbaceous creeping plant belonging to the family Cucurbitaceae. It is mainly propagated by seeds and thrives best in warm areas (Tabiri et al., 2016). The fruits of watermelon exhibit different flesh colours and therefore, have different carotenoid patterns. The fruits are rich in lycopene and with a total antioxidant capacity similar to tomatoes. The fruits are also rich source of $\beta$-carotene, vitamins ( $\mathrm{B}, \mathrm{C}$ and $\mathrm{E})$, minerals $(\mathrm{K}, \mathrm{Mg}, \mathrm{Ca}$ and $\mathrm{Fe}$ ), amino acid (citrulline) and phenolics (Choudhary et al., 2015).

In Nigeria, watermelon seeds are often discarded while the fruit is eaten, although the seeds have been reported to be a rich source of important nutrients (Tabiri et al., 2016). In this study, we reported some qualitative and quantitative phytochemical constituents of watermelon seeds cultivated in Esan Wes Local Government Area of Edo State.

\section{METHODOLOGY}

\section{A. Sample Collection/Identification}

The watermelon (Citrullus Lanatus) was collected from a farm in Iruepken town in Esan West Local Government Area of Edo State. Thereafter, taxonomic identification/authentication was done in the Department of Botany, Ambrose Alli University, Ekpoma before further analysis was carried out in the Chemistry laboratory.

\section{B. Preparation of Sample}

The laboratory bench was washed with running tap water and later with hydrogen hypochlorite (bleach) solution soaked with cotton wool to further clean and disinfect the working area. The Watermelon fruit was washed in tap water, rinse in distilled water, and lastly in deionized water. The watermelon fruit was cut into two (2). It was then cut radially into long slices and the seeds (a black, dark grayish flattened Seeds) removed from the slice fruit by using plastic Spatula and then transferred into a beaker containing tap water. Then it was washed thoroughly with tap water. This was followed with rinsing with distilled water and lastly with deionized water and drained respectively. The Seeds were then air dried at room temperature and later dried in an Oven at $105^{\circ} \mathrm{C}$ for 30 minutes. The weight, length and diameter of the Seeds were measured and taken by using analytical balance and Vanier caliper respectively. The dried seeds were then grinded to powder, weighed and stored for extraction.

\section{Extraction Procedure}

Solvent maceration was carried out by infusing powdered sample in the various solvents in a stoppered container for
24 hours with intermittent agitation until soluble matter was dissolved.

\section{Qualitative phytochemical screening}

a. Detection of alkaloids (Wagner's test)

One gram of extracts were dissolved individually in dilute hydrochloric acid and filtered. Filtrates were treated with Wagner's reagent (iodine in potassium iodide). Formation of brown/reddish precipitate indicates the presence of alkaloids.

\section{b. Detection of carbohydrates (Benedict's test)}

One gram of extracts were dissolved individually in $5 \mathrm{ml}$ distilled water and filtered. The filtrates were used to test for the presence of carbohydrates. Filtrates were treated with Benedict's reagent and heated gently. Orange red precipitate indicates the presence of reducing sugars.

\section{c. Detection of glycosides (Modified Borntrager's test)}

One gram of extracts were hydrolyzed with dilute $\mathrm{HCl}$, and then subjected to test for glycosides. Extracts were treated with ferric chloride solution and immersed in boiling water for 5 minutes. The mixture was then cooled and extracted with equal volume of benzene. The benzene layer was separated and treated with ammonia solution. Formation of rose-pink colour in the ammoniacal layer indicates the presence of anthranol glycosides.

\section{d. Detection of saponins (Froth test)}

One gram of extracts was diluted with distilled water to $20 \mathrm{ml}$ and was followed with shaking in a graduated cylinder for 15 minutes. Formation of $1 \mathrm{~cm}$ layer of foam indicates the presence of saponins.

\section{e. Detection of phytosterols (Liebermann Burchard's test)}

One gram of extracts was treated with $2 \mathrm{ml}$ Chloroform, $2 \mathrm{ml}$ Aceticanhydride and $2 \mathrm{ml}$ conc. Sulphuric acid. Translucent green colour indicated the presence of phytosterols.

\section{f. Detection of phenols (Ferric chloride test)}

One gram of extracts was treated with 4 drops of ferric chloride solution. Formation of bluish black colour indicates the presence of phenols.

\section{g. Detection of tannins (Ferric chloride test)}

Three millilitres of distilled water and few drops of ferric chloride solution were added to $3 \mathrm{ml}$ of the aqueous extract. The formation of green colour precipitate indicates the presence of tannins.

\section{h. Detection of flavonoids (Lead acetate test)}

The extracts $(1 \mathrm{~g})$ were treated with few drops of lead acetate solution. Formation of yellow colour precipitate indicates the presence of flavonoids. 


\section{i. Detection of terpenoids (Salkowski's test)}

Two milliliters of chloroform was added to $5 \mathrm{ml}$ extract of plant sample and mixed with $3 \mathrm{ml}$ of sulphuric acid. Formation of reddish brown colour indicates the presence of terpenoids in the selected plants.

\section{j. Detection of Steroids (Salkowski's test)}

One milligram of the crude plant extracts was put in a test tube and dissolved with $10 \mathrm{ml}$ chloroform, and then equal volume of conc. sulphuric acid was added to the test tube by sides. The turning of the upper layer in the test tube into red and sulphuric acid layer into yellow with green fluorescence shows the presence of steroids.

\section{k. Detection of Triterpenoids}

Five milligrams of the dried crude plant extract was dissolved in $2 \mathrm{ml}$ chloroform and $1 \mathrm{ml}$ acetic anhydride was added to it. $1 \mathrm{ml}$ conc. sulphuric acid was added to the solution. Formation of reddish violet colour shows the presence of triterpenoids.

\section{E Quantitative phytochemical screening}

\section{a. Determination of total phenolic compounds}

The quantity of phenols was determined using the spectrophotometer method. The plant sample was boiled with $50 \mathrm{ml}$ of ethanol for $15 \mathrm{~min} .5 \mathrm{ml}$ of the boiled sample was then taken into $50 \mathrm{ml}$ flask, and $10 \mathrm{ml}$ of distilled water was added. After the addition of distilled water, $2 \mathrm{ml}$ of $\mathrm{NH}_{4} \mathrm{OH}$ solution and $5 \mathrm{ml}$ of concentrated Amyl alcohol were added to the mixture. The sample was made up to the mark and left for 30 min to react for colour development and measured at $505 \mathrm{~nm}$ wavelength using a spectrophotometer (Obadoni and Ochuko, 2001).

\section{b. Determination of total flavonoids}

$10 \mathrm{~g}$ of plant sample was repeatedly extracted with $100 \mathrm{ml}$ of $80 \%$ aqueous methanol at room temperature. The whole solution was then filtered through filter paper and the filtrate was later transferred into a water bath and solution was evaporated to dryness. The sample was then weighed until a constant weight was obtained Boham and Kocipai, 1974).

\section{c. Determination of total alkaloids}

Five grams of the sample was weighed into a $250 \mathrm{ml}$ beaker and $200 \mathrm{ml}$ of $10 \%$ acetic acid in ethanol was added and covered and allowed to stand for 4 hours. The extract was filtered and concentrated on a water bath to one-quarter of the original volume. Conc. ammonium hydroxide was added drop-wise to the extract until the precipitation was completed. The whole solution was allowed to settle and then the precipitate was collected and washed with dilute ammonium hydroxide and then filtered. The residue was the alkaloid, which was dried and weighed (Harborne, 1973).

\section{d. Determination of total tannins}

Five hundred milligrams of the sample was weighed into a $50 \mathrm{ml}$ plastic bottle. $50 \mathrm{ml}$ of distilled water was added and shaken for 1 hour in a mechanical shaker. This was filtered into a $50 \mathrm{ml}$ volumetric flask and made up to the mark with distilled water. Then $5 \mathrm{ml}$ of the filtrate was pipette into a test tube and mixed with $2 \mathrm{ml}$ of $0.1 \mathrm{M} \mathrm{FeCl}_{3}$ in $0.1 \mathrm{~N} \mathrm{HCl}$ and $0.008 \mathrm{M}$ potassium ferrocyanide. Absorbance was measured at $120 \mathrm{~nm}$ within $10 \mathrm{~min}$ (Van-Burden and Robinson, 1981).

\section{e. Determination of total saponins}

Twenty grams of the grinded sample was put into a conical flask and $100 \mathrm{~cm}^{3}$ of $20 \%$ aqueous ethanol was added. Heat was applied on a hot water bath for 4 hours with continuous stirring at about $55^{\circ} \mathrm{C}$. The mixture was filtered and the residue was re-extracted with another $200 \mathrm{ml} \mathrm{20 \%}$ ethanol. The extracts were combined and reduce to $40 \mathrm{ml}$ over water bath at about $90^{\circ} \mathrm{C}$. The concentrate was transferred into a $250 \mathrm{ml}$ separating funnel and $20 \mathrm{ml}$ of diethyl ether was added and then shaken vigorously. The aqueous layer was collected while the ether layer was discarded. Purification process was repeated by adding $60 \mathrm{ml}$ of $\mathrm{n}$-butanol. Washing of the combined n-butanol extracts twice with $10 \mathrm{ml}$ of $5 \%$ aqueous sodium chloride. Heating of the remaining solution was carried out on a water bath. After evaporation, the sample was oven dried and its constant weight was taken to determine the saponins ((Obadoni and Ochuko, 2001).

\section{RESULTS AND DISCUSSION}

The results of the qualitative phytochemical analysis of Citrullus lanatus seeds are presented in Table 1 shows that the concentration of the extracts obtained varied according to the polarity of extracting solvent. The bioactive compounds reported in the sample are known to exhibit medicinal as well as physiological activity (Adeniyi et al., 2012).

The results of the quantitative analysis of the secondary metabolites in the watermelon seed sample are shown in Table 2. Alkaloids had the highest percentage composition of $0.57 \%(28.33 \mathrm{mg} / \mathrm{g})$ while flavonoids had the lowest percentage composition of $0.01 \%(0.67 \mathrm{mg} / \mathrm{g})$. Others include phenol $0.01 \%(0.76 \mathrm{mg} / \mathrm{g})$, tannins $0.022 \%(1.08 \mathrm{mg} / \mathrm{g})$ and saponins $0.084 \%(16.87 \mathrm{mg} / \mathrm{g})$.

Table 2: Quantitative phytochemicals screening of Citrullus lanatus seeds.

\begin{tabular}{lcc}
\hline Phytochemicals & $\begin{array}{c}\text { Amount } \\
(\mathbf{m g} / \mathbf{g})\end{array}$ & $\begin{array}{c}\text { Percentage (\%) } \\
\text { Composition }\end{array}$ \\
\hline Alkaloids & $28.33 \pm 0.58$ & $0.57 \pm 0.01$
\end{tabular}




\begin{tabular}{lcc} 
Tannins & $1.08 \pm 0.03$ & $0.02 \pm 0.00$ \\
Saponins & $16.87 \pm 0.23$ & $0.08 \pm 0.00$ \\
Flavonoids & $0.67 \pm 0.06$ & $0.01 \pm 0.00$ \\
Phenols & $0.76 \pm 0.02$ & $0.02 \pm 0.00$ \\
\hline
\end{tabular}

Results $=$ mean \pm standard deviation

Omoboyowa et al. (2015) reported alkaloid $(33.795 \mathrm{mg} / 100 \mathrm{~g})$, phenol $(1.371 \mathrm{mg} / 100 \mathrm{~g})$, flavonoids $(2.310 \mathrm{mg} / 100 \mathrm{~g})$, tannins $(0.536 \mathrm{mg} / 100 \mathrm{~g})$ and saponins $(1.553 \mathrm{mg} / 100 \mathrm{~g})$ for methanol extract of Citrullus lanatus seed. Gwana, et al. (2014) also reported phytochemical percentage composition of Rosmas variety of watermelon Table 1: Qualitative phytochemicals screening of Citrullus lanatus seeds. seed to contain alkaloid $0.91 \%$, phenol (GAE) $0.01 \%$, flavonoids $0.01 \%$, tannins $0.04 \%$ and saponins $0.09 \%$.

The major activity of medicinal plants against ailments is a function of the amount of secondary metabolite it can produce and as such would produce definite physiological actions in the human body system. However, the scope of this research work did not cover the investigation of the specifics roles of the extracted phytochemicals from watermelon seed; it has however been reported from studies that these secondary metabolites are responsible for many pharmacological actions of plants and vegetables. The presence of alkaloid showed that watermelon seeds can be used as basic medicinal agents for analgesic, antispasmodic

\begin{tabular}{|c|c|c|c|c|c|}
\hline $\begin{array}{l}\text { Test for various } \\
\text { phytochemicals }\end{array}$ & $\begin{array}{l}\text { n-Hexane } \\
\text { extract }\end{array}$ & $\begin{array}{l}\text { Diethyl ether } \\
\text { extract }\end{array}$ & $\begin{array}{l}\text { Chloroform } \\
\text { extract }\end{array}$ & $\begin{array}{l}\text { Ethanol } \\
\text { extract }\end{array}$ & $\begin{array}{l}\text { Water } \\
\text { extract }\end{array}$ \\
\hline $\begin{array}{l}\text { Test for alkaloids } \\
\text { (Wagner's Test) }\end{array}$ & + & + & ++ & + & - \\
\hline $\begin{array}{l}\text { Test for carbohydrates } \\
\text { (Benedict's Test) }\end{array}$ & + & + & + & ++ & ++ \\
\hline $\begin{array}{l}\text { Test for glycosides } \\
\text { (Borntrager's Test) }\end{array}$ & + & + & + & - & + \\
\hline $\begin{array}{l}\text { Test for saponins } \\
\text { (Froth Test) }\end{array}$ & + & + & + & - & + \\
\hline $\begin{array}{l}\text { Test for phytosterols } \\
\text { (Salkowski's Test) }\end{array}$ & + & + & + & - & - \\
\hline $\begin{array}{l}\text { Test for phenols } \\
\text { (Ferric Chloride Test) }\end{array}$ & - & - & - & + & + \\
\hline $\begin{array}{l}\text { Test for tannins } \\
\text { (Ferric Chloride Test) }\end{array}$ & - & - & - & + & + \\
\hline $\begin{array}{l}\text { Test for flavonoids } \\
\text { (Lead acetate Test) }\end{array}$ & + & + & + & ++ & ++ \\
\hline Test for terpenoids & - & + & + & ++ & - \\
\hline Test for steroids & + & + & + & ++ & + \\
\hline Test for triterpenoids & + & + & + & + & ++ \\
\hline
\end{tabular}

$++=$ high concentration $;+=$ moderate concentration $;-=$ absence

and bactericidal effects (Okwu and Okwu, 2004). Studies have shown that, alkaloids are known to have an effect on the central nervous system and some act as a pain killer (such as morphine). The phytochemical screenings of most plants traditionally used to treat malaria have revealed the presence of alkaloid (Eleazu et al., 2010). 


\section{International Journal of Engineering Applied Sciences and Technology, 2020 Vol. 5, Issue 1, ISSN No. 2455-2143, Pages 268-273 \\ Published Online May 2020 in IJEAST (http://www.ijeast.com)}

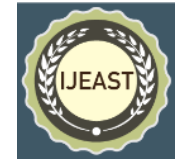

Carbohydrates are the main source of energy. They help fuel the brain, kidneys, heart, muscles and central nervous system. Glycosides are compounds that yield glucose, hydrogen cyanide and aldehyde or ketone upon hydrolysis with an acid or enzyme. Dietary exposure to cyanide occurs mainly in the consumption of food stuffs rich in endogenous cyanide in the form of cyanogenic glycosides. This cyanide could be lethal as it intercalates with cytochrome oxidase for aerobic function. Only free cyanide $\left(\mathrm{CN}^{-}\right)$is toxic and if hydrolysis does not occur, the glycoside remains stable and the food using this product becomes safe. Adewale et al. (2015) reported $(0.02 \pm 0.001 \mathrm{mg} / \mathrm{kg})$ for Cardiac glycosides on the fruit of watermelon which was below the lethal dose $(0.5-3.5 \mathrm{mg} / \mathrm{kg})$ for man.

The presence of saponins is an indication that the plants possess the property of precipitating and coagulating red blood cells. Some of the characteristics include formation of foams in aqueous solutions, hemolytic activity, cholesterol binding properties and bitterness (Omoboyowa et at., 2015). Phytosterols are one of the many nutrients that are claimed to be heart healthy. $2-3$ grams of phytosterols per day, for 3 - 4 weeks, can reduce Low-density lipoprotein (LDL) cholesterol by around 10\% (Katan et al., 2003). Human studies have shown that people who consume the most phytosterols have a lower risk of stomach, lung, breast and ovarian cancer (McCann et al., 2013).

Phenolic compounds have been reported to serve as antioxidants and exhibit a wide range spectrum of medicinal properties such as anticancer, anti-inflammatory and diabetes. Phenolic compounds such as gallotannins, condensed tannins and flavonoids are known to inhibit some molecular targets of pro-inflammatory mediators in inflammatory responses. The phytochemicals also act as antioxidants by scavenging free radicals and thereby attenuate the inflammatory process (Abdelwahab et al., 2011).

Dutta, (2003) reported that, tannins are responsible for the flavour in tea and it use in the treatment of skin eruption. Tannins astringent properties help in the treatment of intestinal disorder. Tannins are dietary anti-nutrients that are responsible for the astringent taste of foods and drinks hence are useful in the food processing industries such as manufacturing of wine. The treatment of sore throat, haemorrhage and wound healing has also been linked to tannins. But if ingested in excessive quantities, tannins inhibit the absorption of minerals such as iron and calcium which may lead to aneamia or osteoporosis if prolonged (Tiwari et al., 2011).

Various in vitro and in vivo bioactivities such as anticancer, anti-inflammatory, and anti-allergic properties by flavonoids have been reported (Okwu, 2004). Flavonoids are good antioxidants and free radical scavengers which help in inhibiting cancer cell activity (Salah et al., 1995). They can lower the risk of arthritis, osteoporosis, allergies and viral disease caused by herpes simplex virus, parainfluenza virus and adenovirus (Okwu, 2004). Plants terpenoids are used extensively for their aromatic qualities and play a role in traditional herbal remedies as they are used as flavour enhancer. Terpenoids exhibit various important pharmacological activities i.e., anti-inflammatory, anticancer, anti-malarial, inhibition of cholesterol synthesis, anti-viral and anti-bacterial activities.

\section{CONCLUSION}

This study has shown that Citrillus lanatus seeds which are often considered waste portion of the fruit are good source of phytochemicals that are biologically important. The study also revealed that cultivation area has no significant effects on the phytochemical concentrations. Hence, their consumption and usage in herbal medicine is further encouraged.

\section{REFERENCES}

[1] Wadood, A., Ghufran, M., Jamal, S.B., Naeem, M., Khan, A., Ghaffar, R., and Asnad, K., (2013). Phytochemical analysis of medicinal plants occurring in local area of Mardan. Biochemistry and Analytical Biochemistry. 2(4):1-4.

[2] Ivanova, D., Gerova, D., Chervenkov, T., and Yankova, T., (2005). Polyphenols and antioxidant capacity of Bulgarian medicinal plants. Journal of Ethnopharmacology. 96:145-150.

[3] Vaghasiya, Y., Dave, R., and Chanda, S., (2011). Phytochemical analysis of some medicinal plants from Western Region of India. Research Journal of Medicinal Plants. 5:567-576.

[4] Jana, S. and Shekhawat, G.S., (2010). Phytochemical analysis and antibacterial screening of in vivo and in vitro extracts of Indian medicinal herb: Anethum graveolens. Research Journal of Medicinal Plants. 4:206-212.

[5] Tabiri, T., Agbenorhevi, J.K., Wireko-Manu, F.D., and Ompouma, E.I., (2016). Watermelon seeds as food: Nutrient composition, phytochemicals and antioxidant activity. International Journal of Nutrition and Food Sciences. 5(2):139-144.

[6] Choudhary, B.R., Haldhar, S.M., Maheshwari, S.K., Bhargava, R., and Sharma, S.K., (2015). Phytochemicals and antioxidants in watermelon (Citrullus lanatus) genotypesunder hot arid region. Indian Journal of Agricultural Sciences. 85(3):414417.

[7] Obadoni, B. and Ochuko, P., (2001). Phytochemical studies and comparative efficacy of the crude extracts of some homostatic plants in Edo and Delta 


\section{International Journal of Engineering Applied Sciences and Technology, 2020 Vol. 5, Issue 1, ISSN No. 2455-2143, Pages 268-273 \\ Published Online May 2020 in IJEAST (http://www.ijeast.com)}

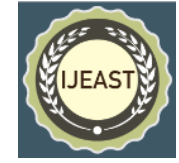

States of Nigeria. Global Journal of Pure Applied Science. 8:203-208.

[8] Boham, B.A. and Kocipai, A.C., (1974). Flavonoids and condensed tannins from leaves of Hawaiian vaccinium vaticulatum and V. calycinium. Pacific Science. 48:458-463.

[9] Harborne, J., (1973). Phytochemical methods. Chapman and Hall Ltd, London.49-88.

[10] Van-Burden, T. and Robinson, W., (1981). Formation of complexes between protein and tannin acid. Journal of Agriculture and Food Chemistry. 1:77.

[11] Adeniyi, S.A., Orjiekwe, C.L., Ehiagbonare, J.E., and Arimah, B.D., ( 2012). Evaluation of chemical composition of the leaves of Ocimum gratissium and Vernonia amygdalina International Journal Biological Chemical Sciences. 6(3):1316-1323.

[12] Omoboyowa, A.D., Outchristian, G., Danladi, G.J., Igara, C.E., Ngobidi, C.K., Okon, M.U., and Agbo, F.A., (2015). Evaluation of chemical compositions of Citruluslanatus seed and Cocos nucifera stem bark African Journal of Food Science and Technology. 6(3):75-83.

[13] Gwana, A.M., Bako, M.M., Bagudu, B.Y., Sadiq, A.B., and Abdullahi, M.M., (2014). Determinations of phytochemical, vitamin, mineral and proximate compositions of varieties of watermelon seeds cultivated in Borno State, North-Eastern Nigeria. International Journal of Nutrition and Food Sciences. 3(4):238-245.

[15] Okwu, D.E. and Okwu, M.E., (2004). Chemical composition of Spondiasmombin Linn. plant parts. Journal of Sustainable Agriculture and Environment. 6(2):140-147.

[16] Eleazu, C.O., Okafor, P.N., and Ahamefuna, I., (2010). Total antioxidant capacity, nutritional composition and inhibitory activity of unripe plantain (Musa paradisiacae) on oxidative stress in alloxan induceddiabetic rabbits. Pakistan Journal of Nutrition. 9:1052-1057.

[17] Adewale, A., Olubukola, S.O., and Olusoji, A.O., (2015). Nutritivevalues and antioxidant activity of Citrullus lanatus fruit extract. Food and Nutrition Sciences. 6:1056-1064.

[18] Okwu, D.E., (2004). Phytochemicals and vitamin content of indigenousspecies of South-Eastern Nigeria. Journal of Sustainable Agriculture and the Environment. 6:30-34.

[19] Katan, M.B., Grundy, S.M., Jones, P., Law, M., Miettinen, T., and Paoletti, R., (2003). Efficacy and safety of plant stanols and sterols in themanagement of blood cholesterol levels. Mayo Clinic Proceedings. 78(8):965-978.

[20] McCann, S.E., Freudenheim, J.L., Marshall, J.R., and Graham, S., (2003). Risk of human ovarian cancer is related to dietary intake of selected nutrients, phytochemicals and food groups. Journal of Nutrition. 133(6):1937-1942.

[21] Abdelwahab, S.I., Hassan, L.E.A., and Sirat, H.M., (2011). Anti-inflammatory activities of Cucurbitacin E isolated from Citrullus lanatus var. Citroides: Role of reactive nitrogen species andcyclooxygenase enzyme inhibition. Fitoterapia. 82:1190-1197.

[22] Dutta, A.C., (2003). Botany for degree students, 6th Edition. Oxford University Press, UK.140-143.

[23] Tiwari, P., Kumar, B., Kaur, M., Kaur, G., and Kaur, H., (2011). Phytochemical Screening and Extraction Review. Internationale Pharmaceutica Sciencia. 1(1):98-106.

[24] Salah, N., Miller, N.J., Pagange, G., Tijburg, L., Bolwell, G.P., Rice, E., and Evans, C., (1995). Polphenolic flavonoids as scavenger of aqueous phase radicals as chain breaking antioxidant. Archieves of Biochemistry and Biophysics. 2:339346. 